\title{
Anti-IL-I7 Agents in the Treatment of Axial Spondyloarthritis
}

\author{
Fabiola Atzeni ${ }^{1}$ \\ Antonio Carriero $\mathbb{I D}^{2,3}$ \\ Laura Boccassini ${ }^{4}$ \\ Salvatore D'Angelo \\ 'Rheumatology Unit, Department of \\ Clinical and Experimental Medicine, \\ University of Messina, Messina, Italy; \\ ${ }^{2}$ Rheumatology Institute of Lucania \\ (IReL), Rheumatology Department of \\ Lucania, San Carlo Hospital of Potenza \\ and Madonna delle Grazie Hospital of \\ Matera, Potenza, Italy; ${ }^{3}$ Translational and \\ Clinical Medicine, Department of \\ Medicine and Health Sciences, University \\ of Molise, Campobasso, Italy; \\ ${ }^{4}$ Rheumatology Unit, Internal Medicine \\ Department, ASST Fatebenefratelli- \\ Sacco, University School of Medicine, \\ Milan, Italy
}

\begin{abstract}
Axial spondyloarthritis (axSpA) describes a group of chronic inflammatory rheumatic diseases primarily involving the axial skeleton. IL-17 is involved in the pathogenesis of numerous inflammatory diseases, including inflammatory arthritis. Until a few years ago, the only biological agents licensed for the treatment of axSpA and nr-axSpA were TNF inhibitors. However, as some patients did not respond to TNF inhibition or experienced secondary failure, the introduction of the first two IL-17 inhibitors (secukinumab [SEC] and ixekizumab [IXE]) has extended the treatment options, and there are now three others (bimekizumab, brodalumab and netakimab) in various stages of clinical development. The last ten years have seen the development of a number of therapeutic recommendations that aimed at improving the management of axSpA patients. The aim of this narrative review of the published literature concerning the role of IL-17 in the pathogenesis of SpA, and the role of IL-17 inhibitors in the treatment of axSpA, is to provide a comprehensive picture of the clinical efficacy and safety of the drugs themselves, and the treatment strategies recommended in the international guidelines.
\end{abstract}

Keywords: spondyloarthritis, ankylosing spondylitis, non radiographic axial spondyloarthritis, axial spondyloarthritis, anti-TNF drugs, anti-IL17 drugs, interleukin 17

\section{Introduction}

The term "axial spondyloarthritis" (axSpA) describes a group of chronic inflammatory rheumatic diseases primarily involving the axial skeleton. These are divided into the two major subtypes of radiographic axSpA (rx-axSpA) or ankylosing spondylitis (AS), and non-radiographic axSpA (nr-axSpA) on the basis of the presence or absence of radiographically detected changes in the sacroiliac joints and/or spine. Both forms are characterised by active inflammation that causes pain, stiffness, and bone formation, and thus leads to severely limited spinal mobility and functional impairment, but they may also involve the entheses and peripheral joints, as well as the eyes, skin and bowel. ${ }^{1,2}$

$\mathrm{Nr}$-axSpA mainly affects females and AS mainly affects males, but there may also be sex-related differences in disease presentation: females often have a high Bath Ankylosing Spondylitis Disease Activity Index (BASDAI) and high Patient Global Assessment (PGA) scores, and more frequently experience fatigue and peripheral involvement, whereas males often have high C-reactive protein (CRP) levels, are positive for HLA B27, and show magnetic resonance imaging (MRI) evidence of inflammation. ${ }^{3-7}$

The main aims of axSpA treatment are to decrease inflammation and prevent or slow structural spinal damage in order to reduce pain and stiffness, and preserve
Correspondence: Fabiola Atzeni Rheumatology Unit, Department of Clinical and Experimental Medicine, University of Messina, Via C. Valeria I, Messina, 98100, Italy

Tel +390902009

Fax +390902000

Email atzenifabiola@hotmail.com 
spinal mobility, and this has led to the introduction of targeted biological agents against TNF and (more recently) IL-17, which are highly effective in reducing disease signs and symptoms, improving physical function, and increasing the quality of life.

The aim of this narrative review of the published literature concerning the role of IL-17 in the pathogenesis of SpA, and the role of IL-17 inhibitors in the treatment of $\operatorname{axSpA}$, is to provide a comprehensive picture of the clinical efficacy and safety of the drugs themselves, and the treatment strategies recommended in the international guidelines.

\section{The Role of IL-I 7}

IL-17 pro-inflammatory cytokines are produced by CD8+ $\mathrm{T}$ cells, $\gamma \delta \mathrm{T}$ cells, natural killer (NK) T cells, mucosal associated invariant (MAI) $\mathrm{T}$ cells, and other cells involved in immune processes. ${ }^{8}$ The most widely studied is IL-17A, the expression of which is regulated by other inflammatory cytokines, including IL-23 which, together with IL-17 in the so-called IL-23/IL-17 axis, makes a crucial contribution to host protection and inflammation., ${ }^{9,10}$

IL-17 is involved in the pathogenesis of numerous inflammatory diseases, including inflammatory arthritis, ${ }^{10,11}$ and its effects on specific cells (eg fibroblasts, epithelial cells and synoviocytes) lead to the transcription of pro-inflammatory genes and the subsequent secretion of pro-inflammatory cytokines (TNF, IL-1, IL-6) and chemokines (CCL20, CCL2, CCL7, CXCL1, CXCL2, CXCL5, CXCL8). ${ }^{12-15}$ It also increases the production of granulomatosis-stimulating factors (G-CSF, GM-CSF), ${ }^{16}$ and regulates the production of antimicrobial peptides (defensins and S100 proteins). ${ }^{17}$ However, despite its protective function, excessive activation of the IL-17 pathway can lead to autoimmune responses or inflammatory diseases: ${ }^{18}$ it can guide the degradation of the joint extracellular matrix in patients with inflammatory arthritis; ${ }^{19,20}$ cause osteoclast activation and bone destruction; ${ }^{21}$ and also promote the angiogenesis that allows inflamed joints to be reached by inflammatory cells. ${ }^{22,23}$

IL-17F plays a similar role to that of IL-17A, but induces a weaker inflammatory response. ${ }^{24}$ It increases the production of certain pro-inflammatory mediators and matrix metalloproteinases in fibroblasts and epithelial cells, ${ }^{25,26}$ and is involved in the neutrophilia associated with severe asthma. ${ }^{27}$
IL-17A and IL-17F therefore both have proinflammatory, osteoclastogenic and angiogenic potential, thus making them critical drivers of inflammation. ${ }^{18}$

The IL-23/IL-17 axis plays a clear role in the pathogenesis of $\mathrm{SpA}{ }^{18}$ Taams et al have reviewed its role in animal models of inflammatory arthritis, discussed the presence of IL-17 family members in the blood and tissue of SpA patients, and investigated the genetic variants involving the axis that leading to susceptibility to SpA. ${ }^{18}$ They have also explored the synergistic effect of IL-17 and other pro-inflammatory cytokines on joint inflammation and altered bone homeostasis. ${ }^{18}$

A number of animal models of inflammatory arthritides, including rheumatoid arthritis (RA) and SpA, have demonstrated the key pathogenetic role of the IL-17 and IL-23 pathways. ${ }^{18}$ It has been shown that the inhibition of IL-17A decreases disease activity and joint damage in an adjuvant-induced model of arthritis. ${ }^{28,29}$ Moreover, IL-17 or IL-17 receptor knockout in an animal model of collagen-induced arthritis (CIA) prevents the development of the disease, which depends on IL-17 in its early phases, is partially suppressed by IL-17 receptor inhibition during the phase of active inflammation, and is exacerbated in terms of severity and joint destruction when IL-17 is overexpressed. ${ }^{30-33}$

One comprehensive review of these animal models ${ }^{34}$ has reported that the overexpression of HLA-B27 in rats leads to the proliferation of IL-17+ $\mathrm{CD} 4{ }^{+} \mathrm{T}$ cells. ${ }^{35,36}$ It has also been shown that the IL-17 produced by IL-23 stimulates arthritis within an SpA syndrome in the SKG mouse model of $\mathrm{RA}^{37-39}$ and that the introduction of exogenous IL-23 stimulates the production of IL-17 and exacerbates enthesitis in the CIA model. ${ }^{40,41}$ Furthermore, IL-17 plays a key role in the development of ankylosis and psoriasislike dermatitis in certain mouse strains. ${ }^{42,43}$

\section{IL-I7A and IL-I7F Cytokines in SpA Patients}

IL-17A and IL-17F have been investigated in fewer studies of SpA than studies of RA, but the results have shown that their serum levels are significantly higher in SpA patients than in healthy subjects. ${ }^{43,44}$ Moreover, serum IL-17 levels in AS patients correlate positively with disease activity. ${ }^{45,46}$ It has also been found that IL-17 levels are higher in the synovial fluid than in the serum of psoriatic arthritis (PsA) patients, ${ }^{47}$ and higher in the synovial fluid of patients with reactive arthritis or 
undifferentiated $\mathrm{SpA}$ than in those with osteoarthritis (OA) or RA. ${ }^{48}$ Furthermore, the expression of IL-17 receptor A is higher in the synoviocytes of PsA and RA patients than in the synoviocytes of patients with OA. ${ }^{49}$

One study has found that the gut (terminal ileum) of AS patients is a significant source of IL-23 but not IL-17. ${ }^{50}$

The only data available concerning IL-17F in SpA patients show that it is more frequently present and more expressed in the synovial tissue of patients with PsA than in OA patients. ${ }^{51,52}$

The synergistic effects of IL-17A and other cytokines and mediators lead to an increased pro-inflammatory response and, although these effects have been explored in only a few studies of SpA, they have been widely studied in RA patients. ${ }^{18}$

The most widely studied is the synergy of IL-17A and TNF. $^{53-55}$

However, the synergistic role of IL-17A and TNF in bone formation and destruction still needs further and more detailed clarification. ${ }^{18}$

IL-17A can also have synergistic effects with other pro-inflammatory cytokines: ${ }^{18}$ together with IL- $1 \beta$, it increases the production of IL- 6 by RA synoviocytes ${ }^{56}$ and the production of CCL20 by fibroblast-like synoviocytes $^{57}$ and, together with IFN $\alpha$, it enhances the expression of intercellular adhesion molecule 1 (ICAM1), thus increasing inflammation in PsA patients. ${ }^{58}$

The lack of robust evidence means that the role of IL-17F in the pathogenesis of SpA still needs to be definitely confirmed, ${ }^{18,59}$ but it is known that it acts synergistically with IL-17A in the process of inflammation $^{52,59}$ and it has been shown that dual IL$17 \mathrm{~A}$ and $\mathrm{IL}-17 \mathrm{~F}$ blockade reduces inflammation better than IL-17A blockade alone. ${ }^{59}$

The mechanisms allowing the synergistic effects of IL17A and IL-17F are not clear, but it has been hypothesised that IL-17A may stabilise mRNA transcripts, thus increasing gene expression and protein production, ${ }^{60}$ and that phospholipase D enzymes may up-regulate cytokine secretion. ${ }^{61}$ For example, although there is no evidence concerning IL-17F, ${ }^{18}$ it has been reported that IL-8 mRNA and other mRNA transcripts (including ACT1, MIP2 and CSF2) are involved in the synergy between TNF and IL17A. ${ }^{15,18}$

Among all of the immunity cell types capable of producing IL-17, it has been shown that a number of $\mathrm{T}$ cell subsets produce IL-17 in patients with SpA. ${ }^{11,62-64}$
1. IL-17+ CD8+ T cells have been identified as potential sources of IL-17 in studies of immune-mediated inflammatory diseases, including psoriasis, multiple sclerosis and PsA (eg in psoriatic skin lesions) ${ }^{58,62,65-70}$ These $\mathrm{T}$ cells can be found in the peripheral blood of patients with AS, and their frequency increases with the severity of the disease ${ }^{71}$ furthermore, they are more frequent in the synovial fluid than in the peripheral blood of both PsA and AS patients. ${ }^{65,72}$ Their immunophenotype shows pro-inflammatory capacity, ${ }^{73}$ and their presence is associated with markers of disease activity such as CRP levels and Doppler findings. ${ }^{65}$ However, increased levels of IL-17-producing CD8 + T cells have not been found in RA patients, ${ }^{65}$ and seem to be related to the development of only HLA class I and not HLA class II-associated SpA. ${ }^{18}$

2. Tissue-resident memory $\left(\mathrm{T}_{\mathrm{RM}}\right) \mathrm{T}$ cells. $\mathrm{CD} 8+\mathrm{T}_{\mathrm{RM}}$ cells express IL-17 and other cytokines in the skin of healthy and psoriatic subjects ${ }^{69,74-76}$ and, although less widely studied, CD4 $+\mathrm{T}_{\mathrm{RM}}$ cells have also been found in human skin. ${ }^{77}$ It has been shown that IL-17-producing $\mathrm{T}_{\mathrm{RM}}$ cells can be considered disease drivers in a mouse model of $\mathrm{SpA},{ }^{78}$ and they may be present in the synovial fluid of patients with juvenile inflammatory arthritis (JIA) ${ }^{79}$ or $\mathrm{SpA},{ }^{73}$ which underlines their importance in the pathogenesis of inflammatory arthritides. ${ }^{18}$

3. MAIT cells. $\mathrm{CD} 8^{+}$MAIT cells (particularly Va7.2/ $\mathrm{IL}-17^{+} \mathrm{CD} 8^{+} \mathrm{T}$ cells) have been identified in the skin and blood of psoriatic patients. ${ }^{80,81}$ They are also more frequently detected in the peripheral blood of AS patients than in the peripheral blood of healthy subjects. $^{82,83}$

4. Invariant NKT cells. Very few studies have described the presence of IL-17-producing NKT cells in SpA patients, but the findings of a murine study suggest that NKT cells may maintain or activate $T_{H} 17$ cells, and thus contribute to the development of inflammation. ${ }^{84}$

5. $\gamma \delta \mathrm{T}$ cells producing IL-17 have been very frequently detected in the peripheral blood of patients with PsA, AS, reactive arthritis, and enthesitisrelated JIA, ${ }^{78,85-87}$ as well as in the synovial fluid of patients with PsA, reactive arthritis, and undifferentiated $\mathrm{SpA}{ }^{87,88}$ It has also been shown that $\gamma \delta$ $\mathrm{T}$ cells produce IL-17 in mouse models of SpA and psoriatic skin inflammation, ${ }^{89-91}$ and accumulate in 
tissues often affected by $\mathrm{SpA}$, such as the entheses, the aortic root, and the eye. ${ }^{92}$

\section{Other Cells}

IL-17 can also be produced by immunity cells other than $\mathrm{T}$ cells, including group 3 innate lymphoid cells (ILC3s), which have been described in the peripheral blood and synovial fluid of PsA patients, where their levels correlate with disease activity. ${ }^{93,94}$ High levels of $\mathrm{CD}^{-} \mathrm{CD} 56+\mathrm{NK}$ cells have been detected in patients with enthesitis-related arthritis, ${ }^{86}$ and IL-17-producing NK cells have been found in the synovial fluid of patients with reactive arthritis or undifferentiated $\mathrm{SpA}{ }^{88}$

Finally, it has been found that mast cells, which were initially hypothesized to be IL-17 producing cells, actually have the function of storing and releasing exogenous IL17A. ${ }^{95,96}$

\section{IL-I 7 Inhibition in axSpA Patients: Randomised Controlled Trials and Real-Life Data}

Until a few years ago, the only biological agents licensed for the treatment of AS and nr-axSpA were TNF inhibitors. However, as some patients did not respond to TNF inhibition or experienced secondary failure, the introduction of the first two IL-17 inhibitors (secukinumab [SEC] and ixekizumab [IXE]) has extended the treatment options, and there are now three others (bimekizumab, brodalumab and netakimab) in various stages of clinical development. ${ }^{97}$

The last ten years have seen the development of a number of therapeutic recommendations aimed at improving the management of axSpA patients. The guidelines of the Assessment of Spondyloarthritis International Society/European League Against Rheumatism (ASAS/ EULAR $)^{98}$ and those of the American College of Rheumatology/Spondylitis Association of America/ Spondyloarthritis Research and Treatment Network $(\mathrm{ACR} / \mathrm{SAA} / \mathrm{SPARTAN})^{99}$ recommend the use of nonsteroidal anti-inflammatory drugs (NSAIDs) and physical therapy in the first-line treatment of pain and stiffness.

As for conventional disease-modifying anti-rheumatic drugs (DMARDs), only sulfasalazine has demonstrated a mild efficacy in treating the axial manifestations of SpA but, as well as methotrexate and leflunomide, it may play a role in the treatment of peripheral SpA solely.
In the case of non-responders to NSAIDs or patients for whom NSAIDs are contraindicated, biological drugs (TNF and IL-17 inhibitors) are strongly recommended. As there is no indication that any one of these is more effective than the others, the choice should be made on the basis of the available safety data, the presence of extraarticular manifestations, and patient preference. Since no predictive factors of good response to IL-17 inhibitors are currently available, treatment response is still far from ideal for many patients, and we lack the biomarkers to predict which medication is most appropriate for an individual patient. The ASAS/EULAR ${ }^{98}$ and ACR/SAA/ SPARTAN $^{99}$ guidelines recommend TNF inhibitors as first line of biologic agents, mainly because of a broader clinical experience and larger pharmacovigilance data with these agents as compared to IL-17 inhibitors. This approach may change in future when real life data and results of comparative and strategy studies on IL-17 inhibitors will be available.

Clinical trials are of course the gold standard for assessing the efficacy and safety of new biological drugs but, as they are conducted under standardized conditions and exclude certain types of patients and/or situations, their findings may not reflect their real-world prescription and use.

\section{Secukinumab}

The efficacy and safety of SEC, a fully human antibody that selectively targets IL-17A and inhibits its interaction with IL-17 receptors, ${ }^{100}$ has been tested in AS patients in one phase $\mathrm{II}^{101}$ and five Phase III trials (MEASURE $1,{ }^{102}$ MEASURE $2,{ }^{103}$ MEASURE 2-J, ${ }^{104}$ MEASURE $3{ }^{105}$ and MEASURE ${ }^{106}$ ) and their extensions. In the Phase II proof-of-concept study, $59 \%$ of the patients in the SEC group showed a week-64 ASAS20 response as against $24 \%$ of the patients receiving placebo (PBO).

MEASURE 1 and $2,{ }^{97}$ which respectively enrolled 371 and 219 patients, tested two doses of the active drug (75 and $150 \mathrm{mg}$ ) against $\mathrm{PBO}$, and had the percentage of patients with a week-16 ASAS20 response as their primary endpoint (Table 1). At the end of the MEASURE 1 study, an ASAS20 response was achieved by $61 \%$ of the patients in the $75 \mathrm{mg}$ group, $60 \%$ of those in the $150 \mathrm{mg}$ group, and $28 \%$ of those in the PBO group; in MEASURE 2, the corresponding figures were respectively $41 \%, 61 \%$ and $28 \% .{ }^{102,103}$ The drug was efficacious regardless of whether it was received by patients as their first biological drug or by patients failing to respond to previous anti-TNF 
Table I Summary of Secukinumab Trials

\begin{tabular}{|c|c|c|c|c|}
\hline & $\begin{array}{c}\text { MEASURE I }{ }^{102} \\
\text { (TNFi-Naïve and TNFi-IR } \\
\text { As Patients) }\end{array}$ & $\begin{array}{l}\text { MEASURE2 }^{103} \\
\text { (TNFi-Naïve and } \\
\text { TNFi-IR As } \\
\text { Patients) }\end{array}$ & $\begin{array}{c}\text { MEASURE3 }^{105} \\
\text { (TNFi-Naïve and TNFi-IR } \\
\text { As Patients) }\end{array}$ & $\begin{array}{c}\text { PREVENT } \\
\text { (nr-axSpA Patients) }\end{array}$ \\
\hline Subjects & 371 & 219 & 226 & 555 \\
\hline Drug regimen & $\begin{array}{l}\text { i.v. SEC } 10 \mathrm{mg} / \mathrm{kg} \text { or matched } \\
\text { PBO week } 0,2 \text { and } 4 \text {, and then } \\
\text { s.c. SEC ( } 75 \text { or } 150 \mathrm{mg} \text { ) or } \\
\text { matched PBO injection every } \\
4 \text { weeks, starting week } 8\end{array}$ & $\begin{array}{l}\text { s.c. SEC ( } 75 \text { or } \\
\text { I } 50 \mathrm{mg} \text { ) or } \\
\text { matched PBO week } \\
0, \mathrm{I}, 2,3 \text { and } 4 \text {, and } \\
\text { then every } 4 \text { weeks }\end{array}$ & $\begin{array}{l}\text { i.v. SEC } 10 \mathrm{mg} / \mathrm{kg} \text { or matched } \\
\text { PBO week } 0,2 \text { and } 4 \text {, and then } \\
\text { s.c. SEC (I50 or } 300 \mathrm{mg} \text { ) or } \\
\text { matched PBO injection every } \\
4 \text { weeks starting week } 8\end{array}$ & $\begin{array}{l}\text { SEC I } 50 \mathrm{mg} \text { LD, SEC I } 50 \mathrm{mg} \\
\mathrm{NL} \text {, or PBO week } 0, \mathrm{I}, 2 \text { and } \\
\text { 3, and then every } 4 \text { weeks } \\
\text { starting week } 4 . \text { The SEC } \\
\text { I50 mg NL group received } \\
\text { PBO in week I, } 2 \text {, and } 3 \text { to } \\
\text { maintain blinding }\end{array}$ \\
\hline $\begin{array}{l}\text { ASAS20 responses } \\
\text { week } 16 \text { (primary } \\
\text { endpoint of } \\
\text { MEASURE I, } 2 \text { and 3; } \\
\text { secondary endpoint } \\
\text { of PREVENT) }\end{array}$ & $\begin{array}{c}60 \%(\mathrm{SEC} 150 \mathrm{mg})^{*} \\
61 \%(\mathrm{SEC} 75 \mathrm{mg})^{*} \\
29 \%(\mathrm{PBO})\end{array}$ & $\begin{array}{c}61 \%(\text { SEC I } 50 \mathrm{mg})^{*} \\
41 \%(\mathrm{SEC} 75 \mathrm{mg}) \\
28 \%(\mathrm{PBO})\end{array}$ & $\begin{array}{c}60.5 \%(\text { SEC } 300 \mathrm{mg})^{*} \\
58.1 \%(\mathrm{SEC} 150 \mathrm{mg})^{* *} \\
36.8 \%(\mathrm{PBO})\end{array}$ & $\begin{array}{l}56.8 \% \text { (SEC I50 mg LD)** } \\
58.2 \% \text { (SEC I50 mg ND)** } \\
45.7 \%(\mathrm{PBO})\end{array}$ \\
\hline $\begin{array}{l}\text { ASAS40 responses } \\
\text { week } 16 \text { (secondary } \\
\text { endpoint of } \\
\text { MEASURE I, } 2 \text { and 3; } \\
\text { primary endpoint of } \\
\text { PREVENT) }\end{array}$ & $\begin{array}{c}42 \%(150 \mathrm{mg})^{*} \\
33 \%(75 \mathrm{mg})^{*} \\
13 \%(\mathrm{PBO})\end{array}$ & $\begin{array}{c}36 \%(\text { SEC I } 50 \mathrm{mg})^{*} \\
26 \%(\text { SEC } 75 \mathrm{mg}) \\
\text { II\% (PBO) }\end{array}$ & $\begin{array}{c}42.1 \%(\mathrm{SEC} 300 \mathrm{mg})^{* *} \\
40.5 \%(\mathrm{SEC} 150 \mathrm{mg})^{* *} \\
21.1 \%(\mathrm{PBO})\end{array}$ & $\begin{array}{l}41.5 \% \text { (SEC I } 50 \mathrm{mg} \text { LD)** } \\
40.8 \% \text { (SEC I } 50 \mathrm{mg} \mathrm{ND})^{*} \\
29.2 \% \text { (PBO) }\end{array}$ \\
\hline ASAS-PR week 16 & $\begin{array}{c}\text { I5\% (SEC I50 mg)* } \\
16 \%(\text { SEC } 75 \mathrm{mg})^{*} \\
3 \%(\mathrm{PBO})\end{array}$ & $\begin{array}{l}\text { I4\% (SEC I } 50 \mathrm{mg})^{*} \\
\text { I } 5 \%(\mathrm{SEC} 75 \mathrm{mg})^{*} \\
4 \%(\mathrm{PBO})\end{array}$ & $\begin{array}{c}21.1 \%(\mathrm{SEC} 300 \mathrm{mg})^{* *} \\
9.5 \%(\mathrm{SEC} 150 \mathrm{mg}) \\
\text { I.3\% (PBO) }\end{array}$ & $\begin{array}{c}21.6 \%(\text { SEC I } 50 \mathrm{mg} \text { LD)* } \\
21.2 \%(\mathrm{SEC} \text { I } 50 \mathrm{mg} \mathrm{ND})^{*} \\
7 \%(\mathrm{PBO})\end{array}$ \\
\hline
\end{tabular}

Notes: $* \mathrm{P}<0.01, * * \mathrm{P}<0.05$ in comparison with placebo.

Abbreviations: AS, ankylosing spondylitis; nr-axSpA, non radiographic axial spondyloarthritis; TNFi, tumour necrosis factor inhibitors; IR, inadequate responders; SEC, secukinumab; i.v., intravenous; s.c., subcutaneous; LD, loading dose; NL, no loading dose; PBO, placebo; PR, partial remission.

treatment. About $80 \%$ of the patients did not experience radiographic progression over a period of two years, ${ }^{107}$ and the drug was well tolerated. ${ }^{108}$

Sustained responses were observed in the 5-year, longterm extension of MEASURE 1, during which $74 \%$ of the patients in the $75 \mathrm{mg}$ group and $79 \%$ of those in the $150 \mathrm{mg}$ group achieved an ASAS20 response, and respectively 54\% and $65 \%$ achieved an ASAS40 response. ${ }^{109,110}$ Among the 150 patients who completed five years' treatment with SEC $150 \mathrm{mg}$ in the extension of MEASURE $2,{ }^{111}$ ASAS20 responses were recorded in $67 \%$ and ASAS40 responses in $50 \%$, and there were sustained improvements in the other efficacy endpoints. The drug's safety profile remained consistent with that described in previous reports. ${ }^{111}$

A pooled analysis of MEASURE 1 and 2 showed that the majority of the SEC-treated patients who achieved remission by week 16 remained in remission for up to three years. $^{112}$

The use of SEC $150 \mathrm{mg}$ in the MEASURE 2-J trial led to sustained improvement in the signs and symptoms of Japanese AS patients for 24 weeks without giving rise to any new or unexpected safety issues. ${ }^{104}$

In the MEASURE 3 trial, in comparison with $36.8 \%$ of the patients receiving $\mathrm{PBO}$, a 16-week ASAS20 response (the primary endpoint) was observed in $60.5 \%$ of the patients treated with SEC $300 \mathrm{mg}(\mathrm{p}<0.01)$ and $58.1 \%$ of those treated with SEC $150 \mathrm{mg}(\mathrm{p}<0.05) .{ }^{105}$ There were improvements in the primary and secondary endpoints in both TNF inhibitor-naïve patients and patients inadequately responding to previous TNF inhibition. ${ }^{113}$ The 52week ASAS20 and ASAS40 response rates in the SEC $150 \mathrm{mg}$ group were respectively $54 \%$ and $41 \%$. $^{105}$ 
MEASURE 4 assessed the long-term efficacy, safety and tolerability of SEC. The initial 16-week treatment was completed by $97 \%$ of the patients, and the subsequent twoyear treatment was completed by $83 \% .{ }^{106}$ The primary endpoint of 16-week ASAS20 responses was not reached because of the very high response rate in the PBO group, ${ }^{109}$ but the drug's two-year safety profile matched that described in previous studies. ${ }^{113}$

PREVENT was the first phase III trial of SEC in active nr-axSpA patients with objective signs of inflammation (MRI with SI joint inflammation and/or high-sensitivity CRP). ${ }^{114}$ The treatment improved disease signs and symptoms throughout the 52-week study period without leading to any new safety findings. The study met both of its primary endpoints: the 16-week ASAS40 response rate was higher among the patients receiving SEC $150 \mathrm{mg}$ with loading doses than among those receiving PBO $(41.5 \%$ vs $29.2 \% ; \mathrm{p}=0.0197)$, and the 52-week ASAS40 response rate was also higher in the patients receiving SEC $150 \mathrm{mg}$ without loading doses $(39.8 \%$ vs $19.9 \% ; \mathrm{p}<0.0021) .{ }^{114}$

A very recent a systematic review and meta-analysis of ten randomized controlled trials (RCTs) assessing the efficacy and safety of IL-17A inhibitors in a total of 2,613 patients with AS (six trials of SEC, two of IXE, and one each of netakimab and bimekizumab) showed that, in comparison with placebo, the IL-17A inhibitors improved both the ASAS20 response rate $(\mathrm{OR}=2.58 ; \mathrm{p}<0.01)$ and the ASAS40 response rate $(\mathrm{OR}=2.80 ; \mathrm{p}<0.01)$. Although the treatment significantly increased the risk of adverse events $(\mathrm{OR}=1.23 ; \mathrm{p}=0.03)$ and nasopharyngitis $(\mathrm{OR}=$ $1.72 ; \mathrm{p}<0.01)$, it did not increase the risk of serious adverse events $(\mathrm{OR}=0.87 ; \mathrm{p}=0.60){ }^{115}$

In 2018, Gentileschi et al described the first real-life experience of the short-term efficacy of SEC in 21 axSpA patients enrolled at three Italian referral centers. Between the start of treatment and the 3-month follow-up visit, there was a statistically significant reduction in the BASDAI $(\mathrm{p}<0.0001)$ and ASDAS-CRP values $(\mathrm{p}=$ 0.0005 ), with no statistically significant difference between the subgroups receiving SEC 150 or $300 \mathrm{mg}$, and no significant difference between the biological treatment-naïve patients and the patients previously treated with TNF inhibitors. No adverse events were reported during the observation period. ${ }^{116}$

The same group also published the findings of a reallife study of the long-term effectiveness of SEC and drug survival in axSpA patients in 2020. There was a statistically significant reduction in the BASDAI and ASDAS-CRP values during the 24-month observation period, with no statistically significant difference between the two doses or between the biological treatment-naïve patients and the patients failing to respond to previous TNF inhibition. The global 24-month drug retention rate was $78.2 \%$, and no adverse event or infectious disease was reported during the study period. ${ }^{117}$

In 2019, Mann et al published findings taken from the Czech ATTRA that showed rheumatologists considered SEC to be equivalent to a TNF inhibitor in the case of biological DMARD-naïve patients and that, after the failure of $\geq 3$ TNF inhibitors, patients were significantly more likely to be treated with SEC. ${ }^{118}$

Elliot and Wright described their experience with SEC in a cohort of 45 patients: 36 with PsA (five of whom had predominant axial disease) and nine with AS. SEC proved to be effective in patients inadequately responding to TNF inhibition in their clinical setting. ${ }^{119}$

Williams et al described the results of their real-world experience of SEC treatment for AS at the Royal National Hospital for Rheumatic Diseases in Bath in 2020, thus providing further evidence that SEC is largely safe and effective. $^{120}$

Also, in 2020, the Spondyloarthritis Roman Group (STRONG) published the results of a multicentre, prospective observational study ${ }^{121}$ showing that SEC improved all of the evaluated clinical parameters and patient-reported outcomes after six and 12 months. The treatment was well tolerated, and drug survival was good, particularly among male AS patients. ${ }^{121}$

Another real-life study of 1,860 axSpA patients in 13 European registries participating in the European Spondyloarthritis Research Collaboration Network was published in 2020. ${ }^{122}$ SEC retention rates after six and 12 months of treatment were respectively $82 \%$ and $72 \%$, and comparable with those observed in studies of TNF inhibition. Response rates were lower than those recorded in the RCTs but consistently better among the biological drug-naïve patients. ${ }^{122}$

A recent systematic review and meta-analysis of reallife studies of the biological drugs used to treat AS has shown that one-year drug survival rate of SEC was 0.77 (95\% confidence interval $0.64-0.90) .{ }^{123}$

A Canadian cost-effectiveness analysis has shown that SEC $150 \mathrm{mg}$ is a more cost-effective option for biological treatment-naïve AS patients than certolizumab pegol, adalimumab, golimumab, etanercept and an etanercept 
biosimilar, or infliximab and an infliximab biosimilar, ${ }^{124}$ and the situation is similar in Finland ${ }^{125}$ and the $\mathrm{UK}^{126}$ for both biological treatment-naïve and biological treatmentexperienced patients with active AS.

The ongoing, longitudinal SERENA study of patients with psoriasis, PsA or AS with an observational period of up to five years is being conducted at 438 centers across Europe and, when its results become available, it will provide valuable information concerning the long-term, real-world effectiveness and safety of SEC. ${ }^{127}$

Two recent real life cohort studies compared effectiveness of treatment with SEC with that of TNF inhibitors. Both studies showed that axSpA patients with prior TNFi exposure treated with SEC experienced comparable outcomes as patients treated with an alternative TNF inhibitor. $^{128,129}$

\section{Ixekizumab}

The efficacy of IXE, an IgG4 monoclonal antibody that has affinity for the homodimer IL-17A and the heterodimer IL-17A/F, in treating radiographic axSpA has been demonstrated in two phase III RCTs (COAST-V ${ }^{130}$ and COAST- $\mathrm{W}^{131}$ ), both of which achieved their primary endpoints and showed significant ASAS40 responses to its administration every two or every four weeks (Table 2).

In the COAST-V trial, which enrolled TNF inhibitornaïve AS or r-axSpA patients, 16-week ASAS40 responses were observed in $51.8 \%$ of those receiving IXE every two weeks, in $48.1 \%$ of those receiving IXE every four weeks, and in $18.6 \%$ of those receiving PBO. ${ }^{130}$ The trial also included a fourth study arm of patients receiving adalimumab $40 \mathrm{mg}$ every two weeks that served as an in-study active reference for comparison. Numerically, the ASAS40 response seen with IXE were similar to those observed in the adalimumab group. Week-52 ASAS40 responses were observed in $53.1 \%$ of the patients treated with IXE every 4 weeks and in $51 \%$ of the patients treated with IXE every 2 weeks. $^{131-134}$

The COAST-W trial enrolled AS or r-axSpA patients inadequately responding to TNF inhibition. Week-16 and week-52 ASAS40 responses were observed in respectively 25.4 and $34.2 \%$ of the patients treated with IXE every four weeks, 30.6 and $30.6 \%$ of those treated with IXE every two weeks. ${ }^{131,134}$

No data are yet available concerning the ability of IXE to inhibit structural progression.

Table 2 Summary of Ixekizumab Trials

\begin{tabular}{|c|c|c|c|}
\hline & $\begin{array}{c}\text { COAST-V }{ }^{130} \\
\text { (TNFi Naïve } r \text {-axSpA Patients) }\end{array}$ & $\begin{array}{l}\text { COAST-W }{ }^{131} \\
\text { (TNFi-IR r-axSpA } \\
\text { Patients) }\end{array}$ & $\begin{array}{c}\text { COAST-X } X^{135} \\
\text { (nr-axSpA Patients) }\end{array}$ \\
\hline Subjects & 341 & 316 & 303 \\
\hline Drug regimen & $\begin{array}{c}\text { s.c. IXE } 80 \text { mg every } 2 \text { or every } 4 \text { weeks; s.c. ADA } \\
40 \text { mg every } 2 \text { weeks (active reference group); or } \\
\text { matching PBO injection every } 2 \text { weeks }\end{array}$ & $\begin{array}{l}\text { s.c. IXE } 80 \text { mg every } 2 \text { or } \\
\text { every } 4 \text { weeks; matching PBO } \\
\text { injection every } 2 \text { weeks }\end{array}$ & $\begin{array}{l}\text { s.c. IXE } 80 \text { mg every } 2 \text { or } \\
\text { every } 4 \text { weeks; matching PBO } \\
\text { injection every } 2 \text { weeks }\end{array}$ \\
\hline $\begin{array}{l}\text { ASAS20 response } \\
\text { week } 16 \text { (secondary } \\
\text { endpoint) }\end{array}$ & $\begin{array}{c}68.7 \% \text { (IXE } 80 \mathrm{mg} \text { Q2W)* } \\
64.2 \% \text { (IXE } 80 \mathrm{mg} \text { Q4W)* } \\
60.5 \% \text { (ADA } 40 \mathrm{mg} \mathrm{Q2W} \text { ) } \\
\text { 40.7\% (PBO) }\end{array}$ & $\begin{array}{l}\text { 46.9\% (IXE 80mg Q2W)** } \\
48.2 \% \text { (IXE 80mg Q4W)** } \\
\text { 29.8\% (PBO) }\end{array}$ & NA \\
\hline $\begin{array}{l}\text { ASAS40 response } \\
\text { week } 16 \text { (primary } \\
\text { endpoint) }\end{array}$ & $\begin{array}{c}51.8 \% \text { (IXE } 80 \mathrm{mg} \text { Q2W) } \dagger \\
48.1 \% \text { (IXE } 80 \mathrm{mg} \text { Q4W) } \dagger \\
36 \% \text { (ADA } 40 \mathrm{mg} \mathrm{Q2W}) \\
\text { I8.6\% (PBO) }\end{array}$ & $\begin{array}{l}30.6 \%(\text { IXE } 80 \mathrm{mg} \text { Q2W) } \ddagger \\
25.4 \%(\text { IXE } 80 \mathrm{mg} \mathrm{Q} 4 \mathrm{~W}) \ddagger \\
\text { I2.5\% (PBO) }\end{array}$ & $\begin{array}{l}40 \% \text { (IXE } 80 \mathrm{mg} \text { Q2W)\# } \\
35 \%(\text { IXE } 80 \mathrm{mg} \mathrm{Q} 4 \mathrm{~W}) \# \\
\text { I9\% (PBO) }\end{array}$ \\
\hline ASAS-PR week 16 & $\begin{array}{c}14.5 \% \text { (IXE } 80 \mathrm{mg} \text { Q2W) } \\
14.8 \% \text { (IXE } 80 \mathrm{mg} \text { Q4W) } \\
15.1 \% \text { (ADA } 40 \mathrm{mg} \text { Q2W) } \\
8.1 \%(\mathrm{PBO})\end{array}$ & $\begin{array}{l}5.1 \% \text { (IXE } 80 \mathrm{mg} Q 2 \mathrm{~W}) \\
6.1 \%(\mathrm{IXE} 80 \mathrm{mg} \mathrm{Q} 4 \mathrm{~W}) \\
\text { I.I\% (PBO) }\end{array}$ & NA \\
\hline
\end{tabular}

Notes: ${ }^{\dagger} \mathrm{P}<0.0001(\mathrm{Q} 2 \mathrm{~W}$ and $\mathrm{Q} 4 \mathrm{~W}) ;{ }^{\ddagger} \mathrm{P}=0.003(\mathrm{Q} 2 \mathrm{~W}), \mathrm{P}=0.017(\mathrm{Q} 4 \mathrm{~W}) ;{ }^{*} \mathrm{P}=0.002(\mathrm{Q} 2 \mathrm{~W}), \mathrm{P}=0.0015(\mathrm{Q} 4 \mathrm{~W}) ;{ }^{*} * \mathrm{P}<0.05(\mathrm{Q} 2 \mathrm{~W}), \mathrm{P}<0.01(\mathrm{Q} 4 \mathrm{~W}) ;{ }^{\#} \mathrm{P}=0.0094(\mathrm{Q} 4 \mathrm{~W})$, $\mathrm{P}=0.0016(\mathrm{Q} 2 \mathrm{~W})$; $\mathrm{P}$ values in comparison with placebo.

Abbreviations: $r$-axSpA, radiographic axial spondyloarthritis; nr-axSpA, non radiographic axial spondyloarthritis; TNFi, tumour necrosis factor inhibitors; IR, inadequate responders; NSAIDs, non-steroidal anti-inflammatory drugs; IXE, ixekizumab; s.c., subcutaneous; PBO, placebo; ADA, adalimumab; NA, not available; Q2W, every two weeks; Q4W, every four weeks; PR, partial remission. 
The efficacy and safety of IXE in patients with nraxSpA was assessed in the COAST-X trial, a phase III RCT that enrolled TNF inhibitor-naïve patients ${ }^{135}$ (Table 2). IXE was superior to PBO after 16 and 52 weeks: 16week ASAS40 responses were observed in $35 \%$ of the patients receiving IXE every four weeks, $40 \%$ of those receiving IXE every two weeks, and $19 \%$ of those receiving PBO; 52-week ASAS40 responses were observed in respectively $30 \%, 31 \%$, and $13 \%$. The adverse events were no different from those found in previous IXE studies, and no new safety issues were identified. ${ }^{136}$ IXE was approved for the treatment of nr-axSpA by the FDA and the EMA in June 2020. ${ }^{137}$

To the best of our knowledge, there are no published real-life observational studies of IXE treatment in axSpA patients.

\section{Efficacy of Secukinumab and Ixekizumab on Extra-Axial Manifestations}

In addition to axial involvement, axSpA patients may also suffer from peripheral arthritis, enthesitis and dactylitis as well as extra-articular manifestations such as psoriasis, uveitis and inflammatory bowel diseases (IBD). These outcomes have not been specifically assessed in the above mentioned SEC and IXE pivotal trials where only axial outcomes have been studied as primary endpoints.

Nevertheless, some information about peripheral arthritis, enthesitis, dactylitis and psoriasis may be drawn from the development programs of IXE and SEC in PsA showing significant improvements for all these features. ${ }^{113}$

Treatment emergent anterior uveitis and IBD were reported in long-term clinical trials (MEASURE and COAST programs) and post marketing safety data in psoriasis, PsA and AS with low overall incidences, within the expected ranges in these disorders. ${ }^{110,111,134,138}$ However, the available data, although limited, would encourage caution in the use of IL-17 inhibition in patients with a history of uveitis or IBD.

Based on the aforementioned data regarding uveitis, IBD and psoriasis, IL-17 inhibitors would not be the first choice in case of associated IBD or uveitis, whereas it would be appropriate in case of psoriasis.

\section{Other IL- 17 Inhibitors}

Brodalumab (an IL-17A receptor antagonist that also inhibits IL-17F, the IL-17A/F heterodimer and IL-17E) is approved for the treatment of psoriasis. ${ }^{139}$ However, a phase III trial involving patients with PsA was interrupted because of concerns about major side effects including depression and suicidal behaviour ${ }^{140}$ (although it is still unclear whether there is a causal relationship between the drug and suicidal ideation and behaviour), and a PBO-controlled phase II trial involving axSpA patients (ClinicalTrials.gov ID NCT02429882) was cancelled and withdrawn in 2015.

The preliminary results of a phase III trial of brodalumab treatment in AS and nr-axSpA patients (ClinicalTrials.gov ID NCT02985983) carried out in Japan were presented at the 2019 EULAR conference. ${ }^{141}$ The week-16 ASAS40 response rate was significantly higher in the brodalumab group $(35 / 80,43.8 \%, \mathrm{p}=0.018)$ than in the PBO group $(19 / 79,24.1 \%)$ and, on the basis of these results, brodalumab may be considered a future therapeutic option for patients with axSpA.

Bimekizumab, an inhibitor of both IL-17A and IL-17F, has been shown to be effective in a phase IIb trial involving AS patients: ${ }^{142}$ significantly more bimekizumab-treated patients achieved a week-12 ASAS40 response than those receiving PBO (non-responder imputation: $29.5 \%$ for bimekizumab $16 \mathrm{mg}$ every four weeks; $42.6 \%$ for bimekizumab $64 \mathrm{mg}$ every four weeks; $46.7 \%$ for bimekizumab $160 \mathrm{mg}$ every four weeks vs $13.3 \%$ for PBO every four weeks; $\mathrm{p}<0.05) .{ }^{132}$ Phase II trials involving AS patients (ClinicalTrials.gov ID NCT03355573 and NCT03215277) and phase III trials involving patients with AS (ClinicalTrials.gov ID NCT03928743), nr-axSpA (ClinicalTrials.gov ID: NCT03928704), or AS and nr-axSpA (ClinicalTrials.gov ID NCT04436640) are currently ongoing.

Netakimab is a recombinant humanized IgG1 anti-IL -17 monoclonal antibody with a modified $\mathrm{Fc}$ fragment and CDR regions. ${ }^{143}$ A Phase III, PBO-controlled trial (ClinicalTrials.gov ID NCT03447704) is currently evaluating the safety and efficacy of a $120 \mathrm{mg}$ dose for up to one year in 228 patients with active AS.

\section{Conclusions}

The IL-23/IL-17 axis plays a clear role in the pathogenesis of SpA. IL-17A and IL-17F have been investigated in few studies of $\mathrm{SpA}$, but their serum levels are significantly higher in SpA patients and correlate positively with disease activity. TNF and (more recently) IL-17 inhibitors have dramatically changed the scenario of axSpA treatment as they are highly effective in reducing disease signs and symptoms, improving physical function, and increasing the quality of life. The results of clinical trials have shown that IL-17 inhibitors are efficacious and safe, and this has been confirmed by some recent real-world data 
concerning a range of unselected patients. The guidelines of the ASAS/EULAR and those of the American College of Rheumatology/Spondylitis Association of America/ Spondyloarthritis Research and Treatment Network (ACR/SAA/SPARTAN) recommend in the case of nonresponders to NSAIDs or patients for whom NSAIDs are contraindicated, biological drugs (TNF and IL-17 inhibitors). Until today, there is no indication that any one of these is more effective than the others, then the choice should be made on the basis of the available safety data, the presence of extra-articular manifestations, and patient preference. However, based on the published data IL-17 inhibitors would not be the first choice in case of associated IBD or uveitis.

\section{Disclosure}

Dr Salvatore D'Angelo reports personal fees from Abbvie, Eli Lilly, Novartis, and UCB, outside the submitted work. The authors reported no other potential conflicts of interest for this work.

\section{References}

1. Taurog JD, Chhabra A, Colbert RA. Ankylosing spondylitis and axial spondyloarthritis. $N$ Engl J Med. 2016;375:1303. doi:10.1056/ NEJMc1609622

2. Rudwaleit M, van der Heijde D, Landewé R, et al. The development of assessment of spondyloarthritis international society classification criteria for axial spondyloarthritis (part II): validation and final selection. Ann Rheum Dis. 2009;68:777-783. doi:10.1136/ard.2009.108233

3. Tournadre A, Pereira B, Lhoste A, et al. Differences between women and men with recent-onset axial spondyloarthritis: results from a prospective multicenter French cohort. Arthritis Care Res. 2013;65:1482-1489. doi:10.1002/acr.22001

4. Akkoc N, Khan MA. ASAS classification criteria for axial spondyloarthritis: time to modify. Clin Rheumatol. 2016;35:1415-1423. doi:10.1007/s10067-016-3261-6

5. Slobodin G, Eshed I. Non-radiographic axial spondyloarthritis. Isr Med Assoc J. 2015;17:770-776.

6. Wallman JK, Kapetanovic MC, Petersson IF, et al. Comparison of nonradiographic axial spondyloarthritis and ankylosing spondylitis patients-baseline characteristics, treatment adherence, and development of clinical variables during three years of anti-TNF therapy in clinical practice. Arthritis Res Ther. 2015;17:378. doi:10.1186/s13075015-0897-6

7. Deodhar A, Mease PJ, Reveille JD, et al. Frequency of axial spondyloarthritis diagnosis among patients seen by US rheumatologists for evaluation of chronic back pain. Arthritis Rheumatol. 2016;68:1669-1676. doi:10.1002/art.39612

8. Rouvier E, Luciani MF, Mattéi MG, et al. CTLA-8, cloned from an activated $\mathrm{T}$ cell, bearing AU-rich messenger RNA instability sequences, and homologous to a herpesvirus saimiri gene. J Immunol. 1993;150:5445-5456.

9. Murphy CA, Langrish CL, Chen Y, et al. Divergent pro- and antiinflammatory roles for IL-23 and IL-12 in joint autoimmune inflammation. $J$ Exp Med. 2003;198:1951-1957. doi:10.1084/jem. 20030896
10. Lubberts E. The IL-23-IL-17 axis in inflammatory arthritis. Nat Rev Rheumatol. 2015;11:562. doi:10.1038/nrrheum.2015.128

11. Korn T, Bettelli E, Oukka M, et al. IL-17 and Th17 cells. Annu Rev Immunol. 2009;27:485-517. doi:10.1146/annurev.immunol. 021908.132710

12. Yao Z, Painter SL, Fanslow WC, et al. Human IL-17: a novel cytokine derived from T cells. J Immunol. 1995;155:5483-5486.

13. Kao CY, Huang F, Chen Y, et al. Up-regulation of CC chemokine ligand 20 expression in human airway epithelium by IL-17 through a JAK-independent but MEK/NF-kappaB-dependent signaling pathway. J Immunol. 2005;175:6676-6685. doi:10.4049/ jimmunol.175.10.6676

14. Shahrara S, Pickens SR, Mandelin AM, et al. IL-17-mediated monocyte migration occurs partially through $\mathrm{CC}$ chemokine ligand 2/monocyte chemoattractant protein-1 induction. J Immunol. 2010;184:4479-4487. doi:10.4049/jimmunol.0901942

15. Hartupee J, Liu C, Novotny M, et al. IL-17 enhances chemokine gene expression through mRNA stabilization. $J$ Immunol. 2007;179:4135-4141. doi:10.4049/jimmunol.179.6.4135

16. Schwarzenberger P, La Russa V, Miller A, et al. IL-17 stimulates granulopoiesis in mice: use of an alternate, novel gene therapy-derived method for in vivo evaluation of cytokines. J Immunol. 1998;161:6383-6389.

17. Liang SC, Tan XY, Luxenberg DP, et al. Interleukin (IL)-22 and IL-17 are coexpressed by Th17 cells and cooperatively enhance expression of antimicrobial peptides. J Exp Med. 2006;20 3:2271-2279. doi:10.1084/jem.20061308

18. Taams LS, Steel KJA, Srenathan U, et al. IL-17 in the immunopathogenesis of spondyloarthritis. Nat Rev Rheumatol. 2018;14:453-466. doi:10.1038/s41584-018-0044-2

19. Chabaud M, Garnero P, Dayer JM, et al. Contribution of interleukin 17 to synovium matrix destruction in rheumatoid arthritis. Cytokine. 2000;12:1092-1099. doi:10.1006/cyto.2000.0681

20. Koenders MI, Kolls JK, Oppers-Walgreen B, et al. Interleukin-17 receptor deficiency results in impaired synovial expression of interleukin-1 and matrix metalloproteinases 3, 9, and 13 and prevents cartilage destruction during chronic reactivated streptococcal cell wall-induced arthritis. Arthritis Rheum. 2005;52: 3239-3247. doi:10.1002/art.21342

21. Kotake S, Udagawa N, Takahashi N, et al. IL-17 in synovial fluids from patients with rheumatoid arthritis is a potent stimulator of osteoclastogenesis. J Clin Invest. 1999;103:1345-1352. doi:10.1172/JCI5703

22. Pickens SR, Volin MV, Mandelin AM, et al. IL-17 contributes to angiogenesis in rheumatoid arthritis. J Immunol. 2010;184:32 33-3241. doi:10.4049/jimmunol.0903271

23. Gullick NJ, Evans HG, Church LD, et al. Linking power Doppler ultrasound to the presence of th 17 cells in the rheumatoid arthritis joint. PLoS One. 2010;5:e12516. doi:10.1371/journal.pone.001 2516

24. Chang SH, Dong C. A novel heterodimeric cytokine consisting of IL-17 and IL-17F regulates inflammatory responses. Cell Res. 2007;17:435-440. doi:10.1038/cr.2007.35

25. Yang XO, Chang SH, Park H, et al. Regulation of inflammatory responses by IL-17F. J Exp Med. 2008;205:1063-1075. doi:10.1084/jem.20071978

26. Kawaguchi M, Adachi M, Oda N, et al. IL-17 cytokine family. J Allergy Clin Immunol. 2004;114:1265-1273. doi:10.1016/j. jaci.2004.10.019

27. Sorbello V, Ciprandi G, Di Stefano A, et al. Nasal IL-17F is related to bronchial IL-17F/neutrophilia and exacerbations in stable atopic severe asthma. Allergy. 2015;70:236-240. doi:10.11 11/all.12547

28. Billingham ME. Models of arthritis and the search for anti-arthritic drugs. Pharmacol Ther. 1983;21:389-428. doi:10.10 16/0163-7258(83)90062-1 
29. Bush KA, Farmer KM, Walker JS, et al. Reduction of joint inflammation and bone erosion in rat adjuvant arthritis by treatment with interleukin-17 receptor IgG1 $\mathrm{Fc}$ fusion protein. Arthritis Rheum. 2002;46:802-805. doi:10.1002/art.10173

30. Nakae S, Nambu A, Sudo K, et al. Suppression of immune induction of collagen-induced arthritis in IL-17-deficient mice. $J$ Immunol. 2003;171:6173-6177. doi:10.4049/jimmunol.171.11.6173

31. Corneth OB, Mus AM, Asmawidjaja PS, et al. Absence of interleukin-17 receptor a signaling prevents autoimmune inflammation of the joint and leads to a Th2-like phenotype in collagen-induced arthritis. Arthritis Rheumatol. 2014;66:34 0-349. doi:10.1002/art.38229

32. Lubberts E, Koenders MI, van den Berg WB. The role of T-cell interleukin-17 in conducting destructive arthritis: lessons from animal models. Arthritis Res Ther. 2005;7:29-37. doi:10.1186/ $\operatorname{ar} 1478$

33. Lubberts E, Joosten LA, van de Loo FA, et al. Overexpression of IL-17 in the knee joint of collagen type II immunized mice promotes collagen arthritis and aggravates joint destruction. Inflamm Res. 2002;51:102-104. doi:10.1007/BF02684010

34. Vieira-Sousa E, van Duivenvoorde LM, Fonseca JE, et al. Review: animal models as a tool to dissect pivotal pathways driving spondyloarthritis. Arthritis Rheumatol. 2015;67:281 3-2827. doi:10.1002/art.39282

35. DeLay ML, Turner MJ, Klenk EI, et al. HLA-B27 misfolding and the unfolded protein response augment interleukin-23 production and are associated with Th17 activation in transgenic rats. Arthritis Rheum. 2009;60:2633-2643. doi:10.1002/art.24763

36. Glatigny S, Fert I, Blaton MA, et al. Proinflammatory Th17 cells are expanded and induced by dendritic cells in spondylarthritis-prone HLA-B27-transgenic rats. Arthritis Rheum. 2012;64:110-120. doi:10.1002/art.33321

37. Sakaguchi N, Takahashi T, Hata H, et al. Altered thymic T-cell selection due to a mutation of the ZAP-70 gene causes autoimmune arthritis in mice. Nature. 2003;426:454-460. doi:10.1038/ nature 02119

38. Ruutu M, Thomas G, Steck R, et al. $\beta$-glucan triggers spondylarthritis and Crohn's disease-like ileitis in SKG mice. Arthritis Rheum. 2012;64:2211-2222. doi:10.1002/art.34423

39. Benham H, Rehaume LM, Hasnain SZ, et al. Interleukin-23 mediates the intestinal response to microbial $\beta$-1,3-glucan and the development of spondyloarthritis pathology in SKG mice. Arthritis Rheumatol. 2014;66:1755-1767. doi:10.1002/art.38638

40. Gillet P, Bannwarth B, Charrière G, et al. Studies on type II collagen induced arthritis in rats: an experimental model of peripheral and axial ossifying enthesopathy. $J$ Rheumatol. 1989; 16:721-728.

41. Sherlock JP, Joyce-Shaikh B, Turner SP, et al. IL-23 induces spondyloarthropathy by acting on ROR- $\gamma \mathrm{t}+\mathrm{CD} 3+\mathrm{CD} 4-\mathrm{CD} 8-$ entheseal resident $\mathrm{T}$ cells. Nat Med. 2012;18:1069-1076. doi: $10.1038 / \mathrm{nm} .2817$

42. Ebihara S, Date F, Dong Y, et al. Interleukin-17 is a critical target for the treatment of ankylosing enthesitis and psoriasis-like dermatitis in mice. Autoimmunity. 2015;48:259-266. doi:10.3109/ 08916934.2014.976630

43. Wendling D, Cedoz JP, Racadot E, et al. Serum IL-17, BMP-7, and bone turnover markers in patients with ankylosing spondylitis. Joint Bone Spine. 2007;74:304-305. doi:10.1016/j. jbspin.2006.11.005

44. Romero-Sanchez C, Jaimes DA, Londoño J, et al. Association between Th-17 cytokine profile and clinical features in patients with spondyloarthritis. Clin Exp Rheumatol. 2011;29:828-834.

45. Chen WS, Chang YS, Lin KC, et al. Association of serum interleukin-17 and interleukin-23 levels with disease activity in Chinese patients with ankylosing spondylitis. J Chin Med Assoc. 2012;75:303-308. doi:10.1016/j.jcma.2012.05.006
46. Xueyi L, Lina C, Zhenbiao W, et al. Levels of circulating Th17 cells and regulatory $\mathrm{T}$ cells in ankylosing spondylitis patients with an inadequate response to anti-TNF- $\alpha$ therapy. $J$ Clin Immunol. 2013;33:151-161. doi:10.1007/s10875-012-9774-0

47. Leipe J, Grunke M, Dechant C, et al. Role of Th17 cells in human autoimmune arthritis. Arthritis Rheum. 2010;62:2876-2885. doi:10.1002/art.27622

48. Singh R, Aggarwal A, Misra R. Th1/Th17 cytokine profiles in patients with reactive arthritis/undifferentiated spondyloarthropathy. J Rheumatol. 2007;34:2285-2290.

49. Raychaudhuri SP, Raychaudhuri SK, Genovese MC. IL-17 receptor and its functional significance in psoriatic arthritis. Mol Cell Biochem. 2012;359:419-429. doi:10.1007/s11010-011-1036-6

50. Ciccia F, Bombardieri M, Principato A, et al. Overexpression of interleukin-23, but not interleukin-17, as an immunologic signature of subclinical intestinal inflammation in ankylosing spondylitis. Arthritis Rheum. 2009;60:955-965. doi:10.1002/ art. 24389

51. van Baarsen LG, Lebre MC, van der Coelen D, et al. Heterogeneous expression pattern of interleukin 17A (IL-17A), IL-17F and their receptors in synovium of rheumatoid arthritis, psoriatic arthritis and osteoarthritis: possible explanation for nonresponse to anti-IL-17 therapy? Arthritis Res Ther. 2014;16:426. doi:10.1186/s13075-014-0426-Z

52. Glatt S, Baeten D, Baker T, et al. Dual IL-17A and IL-17F neutralisation by bimekizumab in psoriatic arthritis: evidence from preclinical experiments and a randomised placebo-controlled clinical trial that IL-17F contributes to human chronic tissue inflammation. Ann Rheum Dis. 2018;77:523-532. doi:10.1136/annrheumdis-2017-212127

53. Zrioual S, Ecochard R, Tournadre A, et al. Genome-wide comparison between IL-17A- and IL-17F-induced effects in human rheumatoid arthritis synoviocytes. $J$ Immunol. 2009;182: 3112-3120. doi:10.4049/jimmunol.0801967

54. Fossiez F, Djossou O, Chomarat P, et al. T cell interleukin-17 induces stromal cells to produce proinflammatory and hematopoietic cytokines. J Exp Med. 1996;183:2593-2603. doi:10.1084/ jem.183.6.2593

55. Zrioual S, Toh ML, Tournadre A, et al. IL-17RA and IL-17RC receptors are essential for IL-17A-induced ELR+ CXC chemokine expression in synoviocytes and are overexpressed in rheumatoid blood. J Immunol. 2008;180:655-663. doi:10.4049/ jimmunol.180.1.655

56. Chabaud M, Fossiez F, Taupin JL, et al. Enhancing effect of IL-17 on IL-1-induced IL-6 and leukemia inhibitory factor production by rheumatoid arthritis synoviocytes and its regulation by Th2 cytokines. J Immunol. 1998;161:409-414.

57. Kawashiri SY, Kawakami A, Iwamoto N, et al. Proinflammatory cytokines synergistically enhance the production of chemokine ligand 20 (CCL20) from rheumatoid fibroblast-like synovial cells in vitro and serum CCL20 is reduced in vivo by biologic disease-modifying antirheumatic drugs. $J$ Rheumatol. 2009;36:2397-2402. doi:10.3899/jrheum.090132

58. Teunissen MB, Koomen CW, de Waal Malefyt R, et al. Interleukin-17 and interferon-gamma synergize in the enhancement of proinflammatory cytokine production by human keratinocytes. J Invest Dermatol. 1998;111:645-649. doi:10.10 46/j.1523-1747.1998.00347.x

59. Wedebye Schmidt EG, Larsen HL, Kristensen NN, et al. TH17 cell induction and effects of IL-17A and IL-17F blockade in experimental colitis. Inflamm Bowel Dis. 2013;19:1567-1576. doi:10.1097/MIB.0b013e318286fa1c

60. Henness S, van Thoor E, Ge Q, et al. IL-17A acts via p38 MAPK to increase stability of TNF-alpha-induced IL-8 mRNA in human ASM. Am J Physiol Lung Cell Mol Physiol. 2006;290:L12831290. doi:10.1152/ajplung.00367.2005 
61. Friday SC, Fox DA. Phospholipase D enzymes facilitate IL-17and $\mathrm{TNF} \alpha$-induced expression of proinflammatory genes in rheumatoid arthritis synovial fibroblasts (RASF). Immunol Lett. 2016;174:9-18. doi:10.1016/j.imlet.2016.04.001

62. Srenathan U, Steel K, Taams LS. IL-17+ CD8+ T cells: differentiation, phenotype and role in inflammatory disease. Immunol Lett. 2016;178:20-26. doi:10.1016/j.imlet.2016.05.001

63. Papotto PH, Ribot JC, Silva-Santos B. IL-17+ $\gamma \delta$ T cells as kickstarters of inflammation. Nat Immunol. 2017;18:604-611. doi:10.1038/ni.3726

64. Hazenberg MD, Spits H. Human innate lymphoid cells. Blood. 2014;124:700-709. doi:10.1182/blood-2013-11-427781

65. Menon B, Gullick NJ, Walter GJ, et al. Interleukin-17+CD8+ $\mathrm{T}$ cells are enriched in the joints of patients with psoriatic arthritis and correlate with disease activity and joint damage progression. Arthritis Rheumatol. 2014;66:1272-1281. doi:10. 1002/art.38376

66. Tzartos JS, Friese MA, Craner MJ, et al. Interleukin-17 production in central nervous system-infiltrating T cells and glial cells is associated with active disease in multiple sclerosis. Am J Pathol. 2008;172:146-155. doi:10.2353/ajpath.2008.070690

67. Ortega C, Fernández-A S, Carrillo JM, et al. IL-17-producing $\mathrm{CD} 8+\mathrm{T}$ lymphocytes from psoriasis skin plaques are cytotoxic effector cells that secrete Th17-related cytokines. J Leukoc Biol. 2009;86:435-443. doi:10.1189/JLB.0109046

68. Res PC, Piskin G, de Boer OJ, et al. Overrepresentation of IL-17A and IL-22 producing CD8 T cells in lesional skin suggests their involvement in the pathogenesis of psoriasis. PLoS One. 2010;5:e14108. doi:10.1371/journal.pone.0014108

69. Hijnen D, Knol EF, Gent YY, et al. CD8(+) T cells in the lesional skin of atopic dermatitis and psoriasis patients are an importan source of IFN- $\gamma$, IL-13, IL-17, and IL-22. J Invest Dermatol. 2013;133:973-979. doi:10.1038/jid.2012.456

70. Di Meglio P, Villanova F, Navarini AA, et al. Targeting CD8(+) T cells prevents psoriasis development. J Allergy Clin Immunol. 2016;138:274-276.e276. doi:10.1016/j.jaci.2015.10.046

71. Wang C, Liao Q, Hu Y, et al. T lymphocyte subset imbalances in patients contribute to ankylosing spondylitis. Exp Ther Med. 2015;9:250-256. doi:10.3892/etm.2014.2046

72. Al-Mossawi MH, Chen L, Fang H, et al. Unique transcriptome signatures and GM-CSF expression in lymphocytes from patients with spondyloarthritis. Nat Commun. 2017;8:1510. doi:10.1038/ s41467-017-01771-2

73. Steel KWS, Srenathan U, Chan E, Kirkham BW, Taams LS. 0016 Synovial IL-17+CD8+ T cells are a pro-inflammatory tissue resident population enriched in spondyloarthritis. Ann Rheum Dis. 2018;77:A8-A9.

74. Cheuk S, Schlums H, Gallais Sérézal I, et al. CD49a expression defines tissue-resident CD8 + T cells poised for cytotoxic function in human skin. Immunity. 2017;46:287-300. doi:10.1016/j. immuni.2017.01.009

75. Cheuk S, Wikén M, Blomqvist L, et al. Epidermal Th22 and Tc17 cells form a localized disease memory in clinically healed psoriasis. J Immunol. 2014;192:3111-3120. doi:10.4049/ jimmunol.1302313

76. Clark RA, Chong B, Mirchandani N, et al. The vast majority of CLA $+\mathrm{T}$ cells are resident in normal skin. $J$ Immunol. 2006;176:4431-4439. doi:10.4049/jimmunol.176.7.4431

77. Watanabe R, Gehad A, Yang C, et al. Human skin is protected by four functionally and phenotypically discrete populations of resident and recirculating memory $\mathrm{T}$ cells. Sci Transl Med. 2015;7:279ra239. doi:10.1126/scitranslmed.3010302

78. Laggner U, Di Meglio P, Perera GK, et al. Identification of a novel proinflammatory human skin-homing $\mathrm{V} \gamma 9 \mathrm{~V} \delta 2 \mathrm{~T}$ cell subset with a potential role in psoriasis. J Immunol. 2011;18 7:2783-2793. doi:10.4049/jimmunol.1100804
79. Petrelli A, van Wijk F. CD8(+) T cells in human autoimmune arthritis: the unusual suspects. Nat Rev Rheumatol. 2016;12:421-428. doi:10.1038/nrrheum.2016.74

80. Dusseaux M, Martin E, Serriari N, et al. Human MAIT cells are xenobiotic-resistant, tissue-targeted, CD161hi IL-17-secreting T cells. Blood. 2011;117:1250-1259. doi:10.1182/blood-2010-08303339

81. Teunissen MBM, Yeremenko NG, Baeten DLP, et al. The IL-17A-producing CD8+ T-cell population in psoriatic lesional skin comprises mucosa-associated invariant $\mathrm{T}$ cells and conventional T cells. $J$ Invest Dermatol. 2014;134:2898-2907. doi:10.1038/jid.2014.261

82. Hayashi E, Chiba A, Tada $\mathrm{K}$, et al. Involvement of mucosal-associated invariant $\mathrm{T}$ cells in ankylosing spondylitis. J Rheumatol. 2016;43:1695-1703. doi:10.3899/ jrheum. 151133

83. Gracey E, Qaiyum Z, Almaghlouth I, et al. IL-7 primes IL-17 in mucosal-associated invariant T (MAIT) cells, which contribute to the Th17-axis in ankylosing spondylitis. Ann Rheum Dis. 2016;75:2124-2132. doi:10.1136/annrheumdis-2015-208902

84. Yoshiga Y, Goto D, Segawa S, et al. Invariant NKT cells produce IL-17 through IL-23-dependent and -independent pathways with potential modulation of Th17 response in collagen-induced arthritis. Int J Mol Med. 2008;22:369-374.

85. Kenna TJ, Davidson SI, Duan R, et al. Enrichment of circulating interleukin-17-secreting interleukin-23 receptor-positive $\gamma / \delta$ T cells in patients with active ankylosing spondylitis. Arthritis Rheum. 2012;64:1420-1429. doi:10.1002/art.33507

86. Gaur P, Misra R, Aggarwal A. Natural killer cell and gamma delta $\mathrm{T}$ cell alterations in enthesitis related arthritis category of juvenile idiopathic arthritis. Clin Immunol. 2015;161:163-169. doi:10.10 16/j.clim.2015.07.012

87. Guggino G, Ciccia F, Di Liberto D, et al. Interleukin (IL)-9/IL-9R axis drives $\gamma \delta \mathrm{T}$ cells activation in psoriatic arthritis patients. Clin Exp Immunol. 2016;186:277-283. doi:10.1111/cei.12853

88. Chowdhury AC, Chaurasia S, Mishra SK, et al. IL-17 and IFN- $\gamma$ producing $\mathrm{NK}$ and $\gamma \delta$-T cells are preferentially expanded in synovial fluid of patients with reactive arthritis and undifferentiated spondyloarthritis. Clin Immunol. 2017;183:207-212. doi:10.1016/j.clim.2017.03.016

89. Cai Y, Shen X, Ding C, et al. Pivotal role of dermal IL-17producing $\gamma \delta \mathrm{T}$ cells in skin inflammation. Immunity. 2011;35:596-610. doi:10.1016/j.immuni.2011.08.001

90. Gray EE, Suzuki K, Cyster JG. Cutting edge: identification of a motile IL-17-producing gammadelta $\mathrm{T}$ cell population in the dermis. J Immunol. 2011;186:6091-6095. doi:10.4049/jimmunol. 1100427

91. Campbell JJ, Ebsworth K, Ertl LS, et al. IL-17-secreting $\gamma \delta$ $\mathrm{T}$ cells are completely dependent upon CCR6 for homing to inflamed skin. J Immunol. 2017;199:3129-3136. doi:10.4049/ jimmunol.1700826

92. Reinhardt A, Yevsa T, Worbs T, et al. Interleukin-23-dependent $\gamma$ / $\delta \mathrm{T}$ cells produce interleukin-17 and accumulate in the enthesis, aortic valve, and ciliary body in mice. Arthritis Rheumatol. 2016;68:2476-2486. doi:10.1002/art.39732

93. Soare A, Weber S, Maul L, et al. Cutting edge: homeostasis of innate lymphoid cells is imbalanced in psoriatic arthritis. J Immunol. 2018;200:1249-1254. doi:10.4049/jimmunol.1700596

94. Leijten EFA, van Kempen TS, Boes M, et al. Brief report: enrichment of activated group 3 innate lymphoid cells in psoriatic arthritis synovial fluid. Arthritis Rheumatol. 2015;67(10):26 73-2678. doi:10.1002/art.39261

95. Noordenbos T, Yeremenko N, Gofita I, et al. Interleukin-17positive mast cells contribute to synovial inflammation in spondylarthritis. Arthritis Rheum. 2012;64:99-109. doi:10.1002/ art.33396 
96. Noordenbos T, Blijdorp I, Chen S, et al. Human mast cells capture, store, and release bioactive, exogenous IL-17A. J Leukoc Biol. 2016;100:453-462. doi:10.1189/jlb.3HI1215-542R

97. Wendling D, Verhoeven F, Prati C. Anti-IL-17 monoclonal antibodies for the treatment of ankylosing spondylitis. Expert Opin Biol Ther. 2019;19:55-64. doi:10.1080/14712598.2019.1554053

98. van der Heijde D, Ramiro S, Landewé R, et al. 2016 update of the ASAS-EULAR management recommendations for axial spondyloarthritis. Ann Rheum Dis. 2017;76:978-991. doi:10.11 36/annrheumdis-2016-210770

99. Ward MM, Deodhar A, Gensler LS, et al. 2019 Update of the American college of rheumatology/spondylitis association of America/spondyloarthritis research and treatment network recommendations for the treatment of ankylosing spondylitis and nonradiographic axial spondyloarthritis. Arthritis Rheumatol. 2019;71:1599-1613. doi:10.1002/art.41042

100. Braun J, Baraliakos X, Kiltz U. Secukinumab (AIN457) in the treatment of ankylosing spondylitis. Expert Opin Biol Ther. 2016;16:711-722. doi:10.1517/14712598.2016.1167183

101. Baeten D, Baraliakos X, Braun J, et al. Anti-interleukin-17A monoclonal antibody secukinumab in treatment of ankylosing spondylitis: a randomised, double-blind, placebo-controlled trial. Lancet. 2013;382:1705-1713. doi:10.1016/S0140-6736(13)611 34-4

102. Baeten D, Sieper J, Braun J, et al. Secukinumab, an interleukin-17A inhibitor, in ankylosing spondylitis. $N$ Engl $J$ Med. 2015;373:2534-2548. doi:10.1056/NEJMoa1505066

103. Sieper J, Deodhar A, Marzo-Ortega H, et al. Secukinumab efficacy in anti-TNF-naive and anti-TNF-experienced subjects with active ankylosing spondylitis: results from the MEASURE 2 study. Ann Rheum Dis. 2017;76:571-592. doi:10.1136/annrheumdis-2016-210023

104. Kishimoto M, Taniguchi A, Fujishige A, et al. Efficacy and safety of secukinumab in Japanese patients with active ankylosing spondylitis: 24-week results from an open-label Phase 3 study (MEASURE 2-J). Mod Rheumatol. 2020;30:132-140. doi:10.1080/14397595.2018.1538004

105. Pavelka K, Kivitz A, Dokoupilova E, et al. Efficacy, safety, and tolerability of secukinumab in patients with active ankylosing spondylitis: a randomized, double-blind phase 3 study, MEASURE 3. Arthritis Res Ther. 2017;19:285. doi:10.1186/ s13075-017-1490-y

106. Kivitz AJ, Wagner U, Dokoupilova E, et al. Efficacy and safety of secukinumab $150 \mathrm{mg}$ with and without loading regimen in ankylosing spondylitis: 104-week results from MEASURE 4 study. Rheumatol Ther. 2018;5:447-462. doi:10.1007/s40744-018-0123-5

107. Braun J, Baraliakos X, Deodhar A, et al. Effect of secukinumab on clinical and radiographic outcomes in ankylosing spondylitis: 2-year results from the randomised phase III MEASURE 1 study. Ann Rheum Dis. 2017;76:1070-1077. doi:10.1136/annrheumdis2016-209730

108. D'Angelo S, Carriero A, Gilio M, et al. Safety of treatment options for spondyloarthritis: a narrative review. Expert Opin Drug Saf. 2018;17:475-486. doi:10.1080/14740338.2018.1448785

109. Torgutalp M, Poddubnyy D. IL-17 inhibition in axial spondyloarthritis: current and future perspectives. Expert Opin Biol Ther. 2019;19:631-641. doi:10.1080/14712598.2019.1605352

110. Baraliakos X, Braun J, Deodhar A, et al. Long-term efficacy and safety of secukinumab $150 \mathrm{mg}$ in ankylosing spondylitis: 5-year results from the phase III MEASURE 1 extension study. RMD Open. 2019;5:e001005. doi:10.1136/rmdopen-2019-001005

111. Marzo-Ortega H, Sieper J, Kivitz AJ, et al. 5-year efficacy and safety of secukinumab in patients with ankylosing spondylitis: end-of-study results from the phase 3 MEASURE 2 trial. Lancet Rheumatol. 2020;2:e339-e346. doi:10.1016/S2665-9913(20)300 66-7
112. Baraliakos X, Van den Bosch F, Machado PM, et al. Achievement of remission endpoints with secukinumab over 3 years in active ankylosing spondylitis: pooled analysis of two phase 3 studies. Rheumatol Ther. 2020. doi:10.1007/s40744020-00269-6

113. Dubash S, Bridgewood C, McGonagle D, et al. The advent of IL-17A blockade in ankylosing spondylitis: secukinumab, ixekizumab and beyond. Expert Rev Clin Immunol. 2019;15:123-134. doi:10.1080/1744666X.2019.1561281

114. Deodhar A, Blanco R, Dokoupilová E, et al. Improvement of signs and symptoms of nonradiographic axial spondyloarthritis in patients treated with secukinumab: primary results of a randomized, placebo-controlled phase III study. Arthritis Rheumatol. 2021;73(1):110-120. doi:10.1002/art.41477

115. Wang $\mathrm{P}$, Zhang $\mathrm{S}, \mathrm{Hu} \mathrm{B}$, et al. Efficacy and safety of interleukin-17A inhibitors in patients with ankylosing spondylitis: a systematic review and meta-analysis of randomized controlled trials. Clin Rheumatol. 2021. doi:10.1007/s10067020-05545-y

116. Gentileschi S, Vitale A, Rigante D, et al. Prompt clinical response to secukinumab in patients with axial spondyloarthritis: real life observational data from three italian referral centers. Isr Med Assoc J. 2018;20:438-441.

117. Gentileschi S, Rigante D, Sota J, et al. Long-term effectiveness of secukinumab in patients with axial spondyloarthritis. Mediators Inflamm. 2020;2020:6983272. doi:10.1155/2020/6983272

118. Mann HF, Závada J, Šenolt L, et al. Real world use of secukinumab for treatment of axial spondyloarthritis and psoriatic arthritis: nationwide results from the ATTRA registry. Clin Exp Rheumatol. 2019;37:342-343.

119. Elliott A, Wright G. Real-world data on secukinumab use for psoriatic arthritis and ankylosing spondylitis. Ther $A d v$ Musculoskelet Dis. 2019;11:1759720X19858510. doi:10.1177/ 1759720X19858510

120. Williams T, Wadeley A, Bond D, et al. Real-world experience of secukinumab treatment for ankylosing spondylitis at the Royal National Hospital for Rheumatic Diseases, Bath. Clin Rheumatol. 2020;39:1501-1504. doi:10.1007/s10067-02004944-5

121. Chimenti MS, Fonti GL, Conigliaro P, et al. One-year effectiveness, retention rate, and safety of secukinumab in ankylosing spondylitis and psoriatic arthritis: a real-life multicenter study. Expert Opin Biol Ther. 2020;20:813-821. doi:10.1080/14712 598.2020.1761957

122. Michelsen B, Lindström U, Codreanu C, et al. Drug retention, inactive disease and response rates in 1860 patients with axial spondyloarthritis initiating secukinumab treatment: routine care data from 13 registries in the EuroSpA collaboration. RMD Open. 2020;6(3):e001280. doi:10.1136/rmdopen-2020-001280

123. Yu CL, Yang CH, Chi CC. Drug survival of biologics in treating ankylosing spondylitis: a systematic review and meta-analysis of real-world evidence. BioDrugs. 2020;34:669-679. doi:10.1007/ s40259-020-00442-x

124. Goeree R, Chiva-Razavi S, Gunda P, et al. Cost-effectiveness analysis of secukinumab in ankylosing spondylitis from the Canadian perspective. J Med Econ. 2019;22:45-52. doi:10.1080/ 13696998.2018.1539400

125. Purmonen T, Puolakka K, Mishra D, et al. Cost-effectiveness of secukinumab compared to other biologics in the treatment of ankylosing spondylitis in Finland. Clinicoecon Outcomes Res. 2019;11:159-168. doi:10.2147/CEOR.S192235

126. Emery P, Van Keep M, Beard S, et al. Cost effectiveness of secukinumab for the treatment of active ankylosing spondylitis in the UK. Pharmacoeconomics. 2018;36:1015-1027. doi:10.10 07/s40273-018-0675-9 
127. Kiltz U, Sfikakis PP, Gaffney K, et al. Secukinumab use in patients with moderate to severe psoriasis, psoriatic arthritis and ankylosing spondylitis in real-world setting in Europe: baseline data from SERENA study. Adv Ther. 2020;37:2865-2883. doi:10.1007/s12325-020-01352-8

128. Micheroli R, Tellenbach C, Scherer A, et al. Effectiveness of secukinumab versus an alternative TNF inhibitor in patients with axial spondyloarthritis previously exposed to TNF inhibitors in the Swiss Clinical Quality Management cohort. Ann Rheum Dis. 2020;79:1203-1209. doi:10.1136/annrheumdis-2019-215934

129. Glintborg B, Lindstrom U, Di Giuseppe D, et al. One-year treatment outcomes of secukinumab versus tumor necrosis factor inhibitors in Spondyloarthritis. Arthritis Care Res. 2020. doi:10.1002/acr.24523

130. van der Heijde D, Cheng-Chung Wei J, Dougados M, et al. Ixekizumab, an interleukin-17A antagonist in the treatment of ankylosing spondylitis or radiographic axial spondyloarthritis in patients previously untreated with biological disease-modifying anti-rheumatic drugs (COAST-V): 16 week results of a phase 3 randomised, double-blind, active-controlled and placebo-controlled trial. Lancet. 2018;392:2441-2451. doi:10.1016/S0140-6736(18) 31946-9

131. Deodhar A, Poddubnyy D, Pacheco-Tena C, et al. Efficacy and safety of ixekizumab in the treatment of radiographic axial spondyloarthritis: sixteen-week results from a phase III randomized, double-blind, placebo-controlled trial in patients with prior inadequate response to or intolerance of tumor necrosis factor inhibitors. Arthritis Rheumatol. 2019;71:599-611. doi:10.1002/ art.40753

132. Ritchlin C, Adamopoulos IE. Axial spondyloarthritis: new advances in diagnosis and management. BMJ. 2021;372:m4447. doi:10.1136/bmj.m4447

133. Rademacher J, Poddubnyy D. Emerging drugs for the treatment of axial spondyloarthritis. Expert Opin Emerg Drugs. 2018;23:83-96. doi:10.1080/14728214.2018.1445719

134. Dougados M, Wei JC, Landewé R, et al. Efficacy and safety of ixekizumab through 52 weeks in two phase 3 , randomised, controlled clinical trials in patients with active radiographic axial spondyloarthritis (COAST-V and COAST-W). Ann Rheum Dis. 2020;79:176-185. doi:10.1136/annrheumdis-2019-216118
135. Deodhar A, van der Heijde D, Gensler LS, et al. Ixekizumab for patients with non-radiographic axial spondyloarthritis (COAST-X): a randomised, placebo-controlled trial. Lancet. 2020;395:53-64. doi:10.1016/S0140-6736(19)32971-X

136. Kiwalkar S, Beier S, Deodhar A. Ixekizumab for treating ankylosing spondylitis. Immunotherapy. 2019;11:1273-1282. doi:10. 2217/imt-2019-0094

137. San Koo B, Kim TH. The role of ixekizumab in non-radiographic axial spondyloarthritis. Ther Adv Musculoskelet Dis. 2021;13:1759720X20986734. doi:10.1177/1759720X20986734

138. Schreiber S, Colombel JF, Feagan BG, et al. Incidence rates of inflammatory bowel disease in patients with psoriasis, psoriatic arthritis and ankylosing spondylitis treated with secukinumab: a retrospective analysis of pooled data from 21 clinical trials. Ann Rheum Dis. 2019;78:473-479. doi:10.1136/annrheumdis2018-214273

139. Papp KA, Leonardi C, Menter A, et al. Brodalumab, an anti-interleukin-17-receptor antibody for psoriasis. $N$ Engl J Med. 2012;366:1181-1189. doi:10.1056/NEJMoa1109017

140. Lebwohl MG, Papp KA, Marangell LB, et al. Psychiatric adverse events during treatment with brodalumab: analysis of psoriasis clinical trials. J Am Acad Dermatol. 2018;78:81-89.e85. doi:10.1016/j.jaad.2017.08.024

141. Wei JCC, Kim TH, Kishimoto M, et al. OP0234 efficacy and safety of brodalumab, an anti-interleukin-17 receptor a monoclonal antibody, in patients with axial spondyloarthritis: a 16 week results of a phase 3, multicenter, randomized, double-blind, placebo-controlled study. Ann Rheum Dis. 2019;78:195. doi:10.1136/annrheumdis-2019-eular.6888

142. van der Heijde D, Gensler LS, Deodhar A, et al. Dual neutralisation of interleukin-17A and interleukin-17F with bimekizumab in patients with active ankylosing spondylitis: results from a 48-week phase IIb, randomised, double-blind, placebo-controlled, dose-ranging study. Ann Rheum Dis. 2020;79:595-604. doi:10.1136/annrheumdis-2020-216980

143. Erdes S, Nasonov E, Kunder E, et al. Primary efficacy of netakimab, a novel interleukin-17 inhibitor, in the treatment of active ankylosing spondylitis in adults. Clin Exp Rheumatol. 2020;38:27-34.

\section{Publish your work in this journal}

ImmunoTargets and Therapy is an international, peer-reviewed open access journal focusing on the immunological basis of diseases, potential targets for immune based therapy and treatment protocols employed to improve patient management. Basic immunology and physiology of the immune system in health, and disease will be also covered. In addition, the journal will focus on the impact of management programs and new therapeutic agents and protocols on patient perspectives such as quality of life, adherence and satisfaction. The manuscript management system is completely online and includes a very quick and fair peer-review system, which is all easy to use. Visit http://www.dovepress.com/testimonials.php to read real quotes from published authors. 